\title{
فعالية برنامج قائم على استراتيجية لعب الأدوار فى تنمية مهارات التعبير الشفهى ئهي لدى طفل الروضة
}

\author{
إعراد \\ الباحثة/ سماح محمد عبدالله السيد
}

$$
\text { غن إشرافـ }
$$

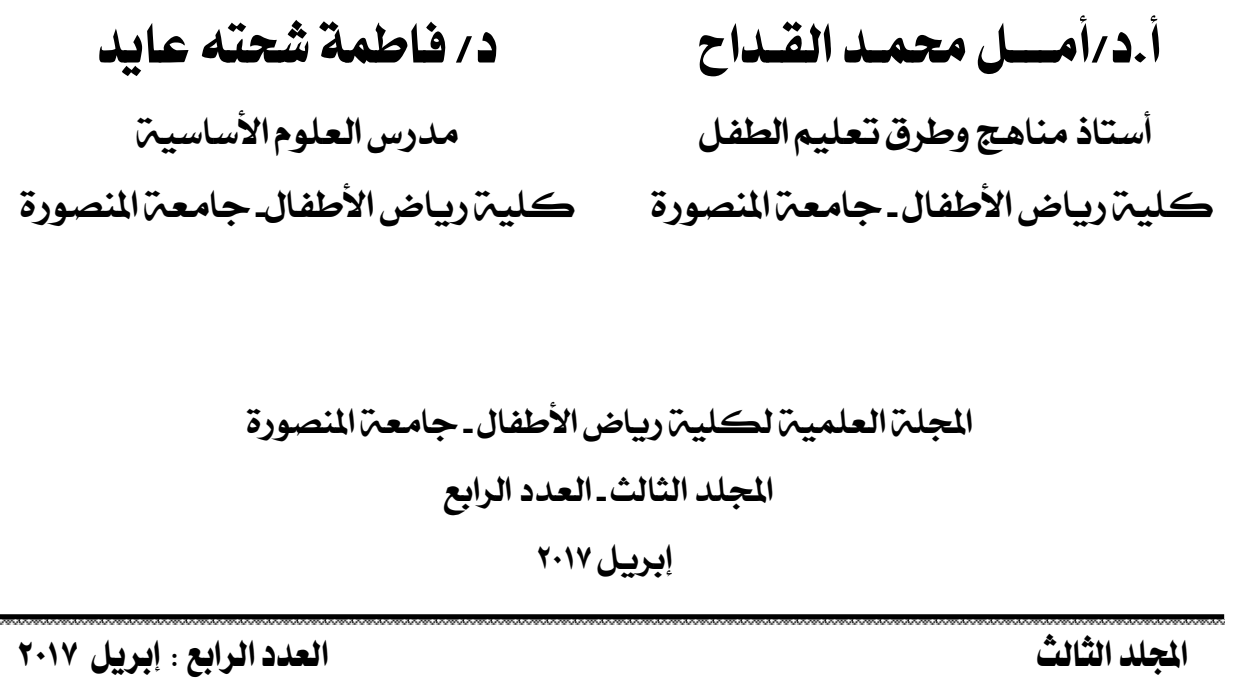




\section{فعالية برنامج قائم على استراتيجية لعب الأدوار فى

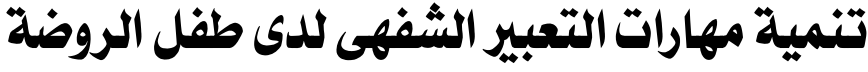

أرسماح محمد عبدالله السيد"*

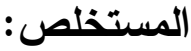

تهدف هذه الدراسة إلى إعداد برنامج لتتمية مهـار ات التعبيــر الـشفهي

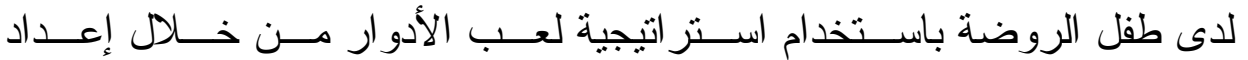

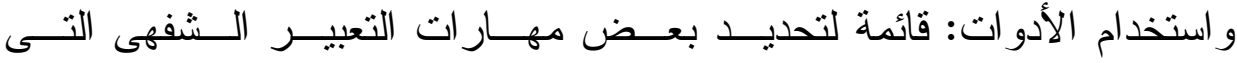

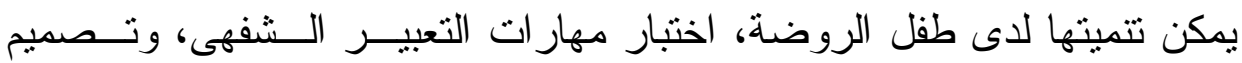
برنامج تتمية مهارات التعبير الثفهى باستخدام استر اتيجية لعب الأدوار(الأدوات

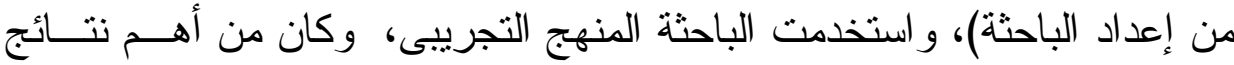

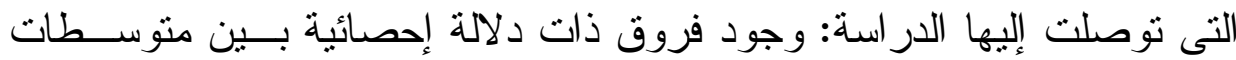

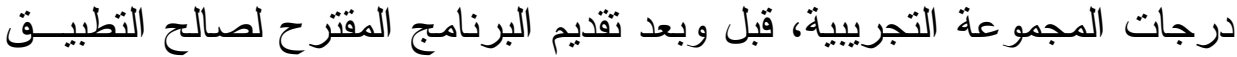
البعدى.

" باحث دكتوراه - كليترياض الأطفال -جامعت المنصورة **

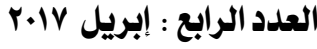




\section{فعالية برنامج قائم على استراتيجية لعب الأدوار فى

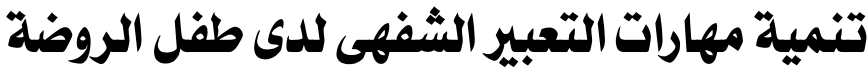

أر سماح محمد عبدالله السيد*"

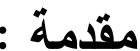

تعد اللغة العربية الأداة الرئيسية التى تستخدم فى مختلف العلوم و الفنون

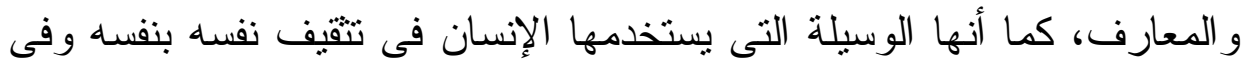
تعليمه الذاتى، وهى إلى جانب ذللك وعاء للفكر ووسيلة للاتصال و التفاهم التها ورابطة قومية وحسب؛ فاللغة العربية فخرا أن تكون لغة القرآن الكريم ولغة

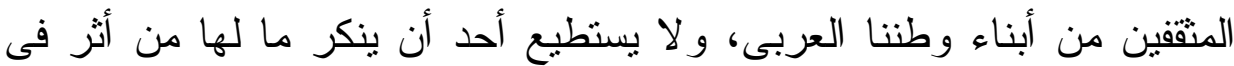
تكوين عقلية الإنسان العربى وتدبير تفكيره وتصريف أفعاله وهداية سلوكه تقوق كل أثز سواه، فضلا عن المشاركة الروحية العميقة ومشاركة العقيدة ومشاركة التر اث و الحضارة التى تقوم على الوعى النابع من تلك اللغة.

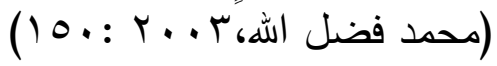

و التعبير الثفهى يعد الوسيلة التى يتم من خلالها التواصل بين الطفل و المحيطين به، فهو الذى يكثف عنما يشعر به من انفعالات، و عما براوده من التهن أفكار وخبرات، فقدرة الطفل على التواصل اللغوى لا يتم في إطار النظام اللغوى الذى يصيغ فيه الطفل ما يريد تبليغه للآخرين أو ما يريد التعبير عنها،

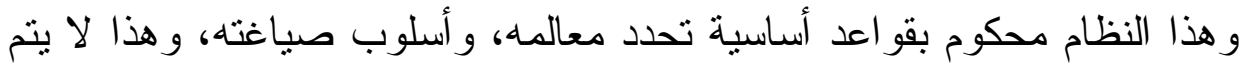
بطريقة عشوائية؛ و إنما طبقا لمراحل نمو مختلفة تتكامل فيما بينها

$$
\text { " باحث دكتوراه - كليترياض الأطفال - جامعت المنصورة }
$$


لنظهر هذه اللغة في إطارها المفسر الموضح للأفكار و الآراء.(طاهرة

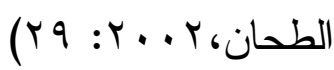

وهناك العديد من استراتيجيات التعلم النشط التى بمكن استخدامها لتتمية اللغة لدى الطفل ومنها استراتيجية لعب الدور يمكن استخدامها بفاعلية بالروضة، كما أن هذه الاستراتيجية يمكن نوظيفها فى العديد من الأنشطة

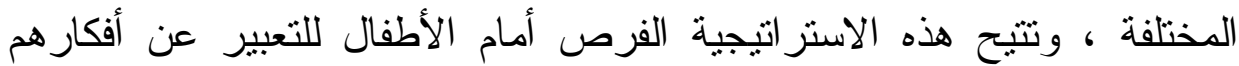
ومشاعر هم وقيمهم و اتجاهاتهم كما هى، ويعكسون اتجاهات و أفكار ومشاعر لإنير الآخرين يمكن فهمها وتفحصها بتأدية أدو ار منظمة مخططة بإنثر اف المعلمة، ولهات ولهذه الاستراتيجية مزايا مختلفة تعود بفوائدها التزبوية و التعليمية على كل بائتل

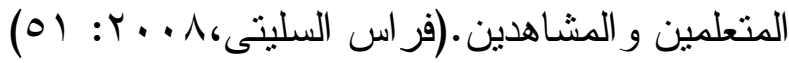

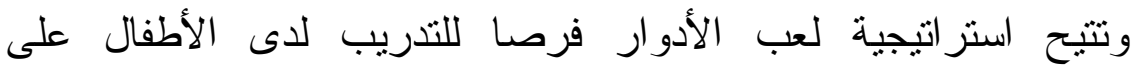
احترام الدور واستخدام اللغة فى التخطيط وتتفيذ الأدوار، مع إضافة أحيانا قدرا من التعبيرات مبتعدين عن مركزية الذات لديهم، فيعتبر لعب الأدوار طريقة طبيعة لامج اللغة فى بيئة الطفل وتصبح جز عا هاما وطبيعيا من مشاهد

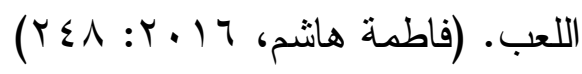

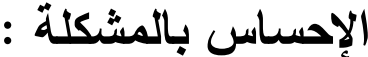

تتمتل أهمية التعبير الثفههى فى المر احل التعليمية المختلفة بـصف عامــة

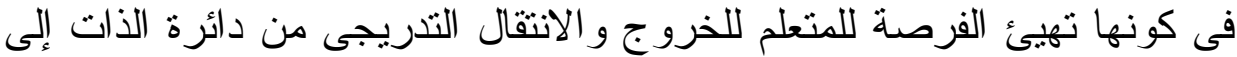

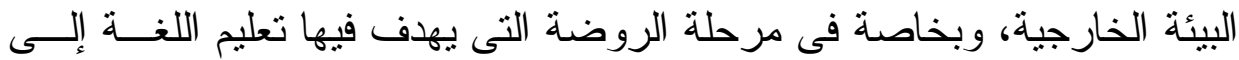

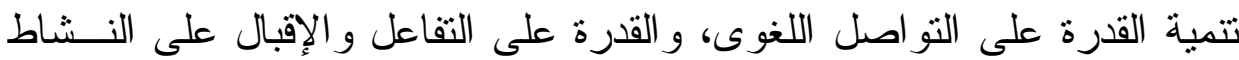
اللغوى، و انطلاقاً من هذه الأهمية نم الاطلاع على العديد من الدر اسات الـسابقة

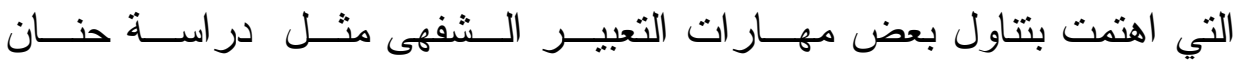




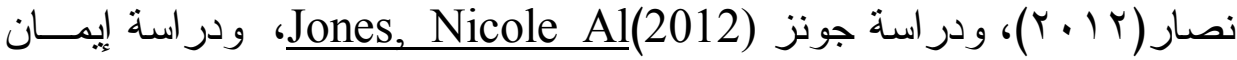

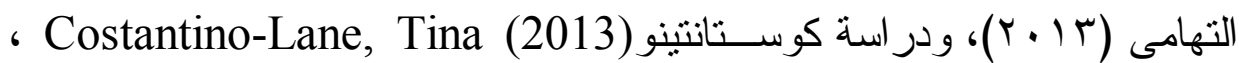
وأيضا در اسة كوبف (2013). Kopf, D

وقد أكدت هذه الدراسات على أن هناك قصورا فى مهارات التعبير الثفهى لدى طفل الروضة، بالإضافة إلى نتائج العديد من الدر اسات السابقة التى التى التى أكدت على دور استر اتيجية لعب الأدوار فى مرحلة الروضة مثل دراسة نفين

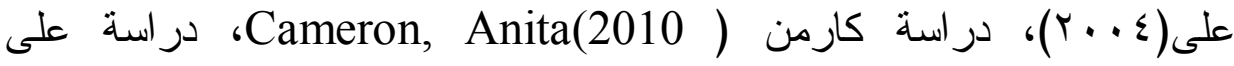

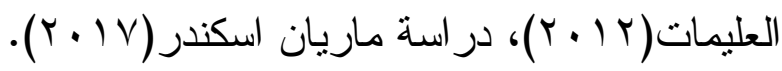
لذا فإن الدر اسة الحالية هى محاولة للتغلب على هذا القصور ؛ وذلك من

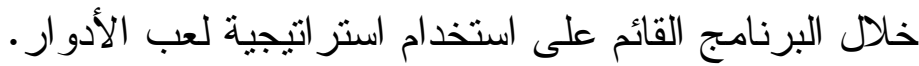
مشكلة الار اسة: ويمكن صياغة مشكلة الاراسة فى التساؤل الرئيس التالى: ما فعالية برنامج مقترح لتتمية مهارات التعبير الثفهى باستخدام استر اتيجية لعب الأدو ار لدى طفل الروضة؟ لئج ويتفرع عن ذلك التساؤلات الآتية: 1- ما مهار ات التعبير الثفهي التي ينبنى تتميتها لدى طفل الروضة؟ r- ما أثز استخدام استر اتيجية لعب الأدوار فى نتمية بعض مهار ات التعبير

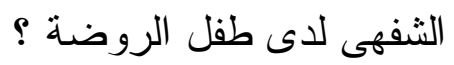
r-ما البرنامج المقترح لتتمية مهارات التعبير الثفهى باستخدام استر اتيجية

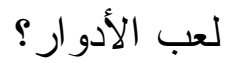


ع- ما فعالية البرنامج المقترح فى تتمية مهار ات التعبير الثفهى لدى طفل

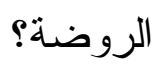

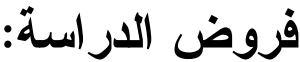

فى ضوء مشكلة الدر اسة الحالية و أهدافها ونتائج الدراسات و البحوث السابقة، تسعى الدر اسة للتحقق من صحة الفروض التالية:

1-يوجد فرق ذو دلالة إحصائية عند مستوى دلالة (0.05) بين متوسطى

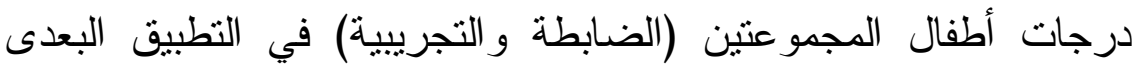
لاختبار التعبير الثفهى لصالح المجموعة التجريبية.

ז-يوجد فرق ذو دلالة إحصائية عند مستوي دلالة(0.05) بين منوسطي

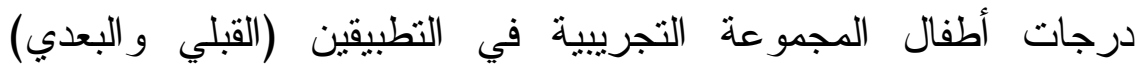
لاختبار مهار ات التعبير الثفههى قبل وبعد تقديم البرنامج الدقتر ح لصالح

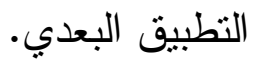

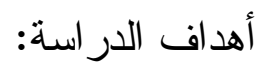

1- تحديد مهار ات التعبير الثفهي التى يجب تتميتها لدى طفل الروضة. r- استخدام استراتيجية لعب الأدوار فى تتمية مهارات التعبير الثفهى لدى

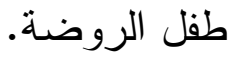
r- إعداد برنامج مقترح لتتمية مهار ات التعبير الثفهى باستخدام استر اتيجية لعب الأدو ار لدى طفل الروضة. ع- تحديد فعالية البرنامج المقترح لتتمية مهارات التعبير الثفهى باستخدام

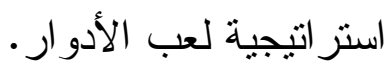


من المتوقع أن تفيد الاراسة الحالية فى:

1- تتمية بعض مهار ات التعبير الثفهى لدى طفل الروضة من خلال استخدام

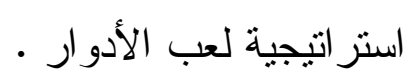

r- إمداد المعلمين القائمين على تعليم طفل الروضة:

أ- باختبار لقياس مهار ات التعبير الثفهى عند الأطفال .

ب-بأنشطة لعب الأدوار التى تساعدهم على تتمية بعض مهار ات التعبير

$$
\text { الثفهى. بالثطه. }
$$

جـ- بأساليب ووسائل مناسبة فــى تتميــة بعـض مهــار ات التعبيــر

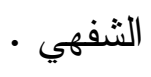

r- مساعدة و اضعى مناهج طفل الروضة: حيث بسنطيعون فى ضو ء نتــائج

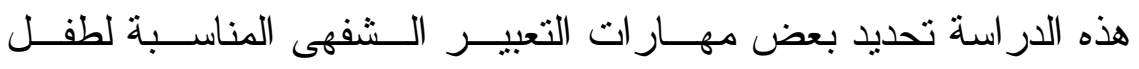

$$
\text { منهج الار اسة : الروضة. }
$$

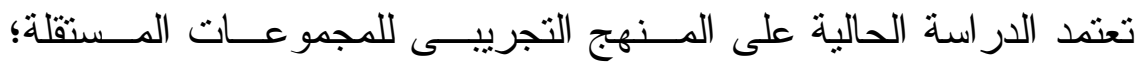

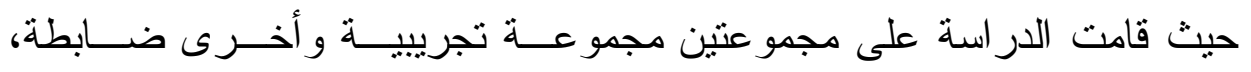

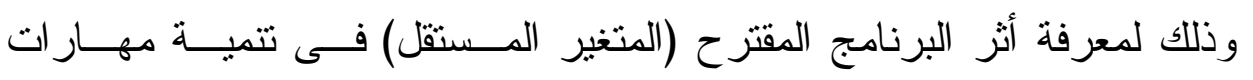

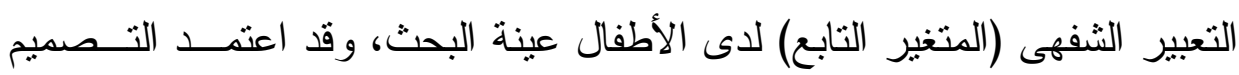

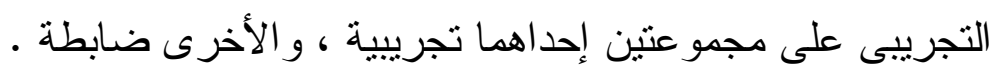




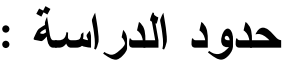

1-عينة من أطفال الروضة المستوى الثانى من(0-7) سنوات برياض

الأطفال التابعة لوز ارة الثزبية و التعليم بمحافظة الدقهلية.

ץ- استخدام استر اتيجية لعب الأدو ار لتتمية دهار ات التعبير الثفهى لدى طفل

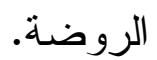

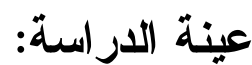

تكونت العينة من( • V) طفلا؛ حيث نم تقسيم العينة للمجمو عنين: مجموعة

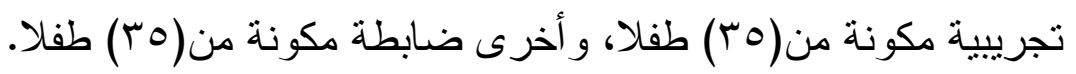

أدوات الار اسة:

1- اسنبانة تحديد مهار ات التعبير الثفهى لاى طفل الروضة. (إعداد الباحثة)

r- اختبار مهار ات التعبير الثففهى. (إعداد الباحثة)

r- بالإضافة إلى إعداد برنامج مقترح قائم على استخدام استر اتيجية لعب

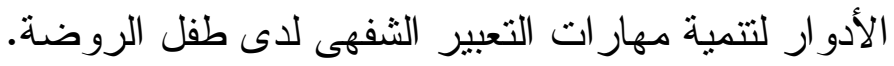

مصطلحات الار اسة

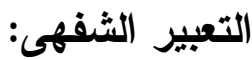

تعرفه الباحثة إجر ائيا:تعبير الطفل بكلمات و اضحة وجمــل بـسيطة فـى

المو اقف المختلفة.

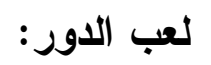

تعرفه الباحثة إجر ائيا: أسلوب شيق يقوم فيه الطفل بأداء بعـض الأدوار

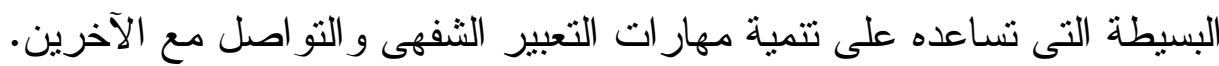


أ-- الهدف من إعداد الاسنبانة: تحديد مهار ات التعبير الثفهى اللازمة لطفـلـل

$$
\text { الروضة. }
$$

ب- المصادر التى اعتمدت عليها الباحثة فى انتقاق مهارات التعبير الـشفهى لروضى

$$
\text { ووضعها فى قائمة: }
$$

- البحوث و الدر اسات السابقة و الأدبيات (العربيــة، و الأجنبيــة) التـى فئس اهتمت بنتمية مهارة التعبير الثفهى.

ت- تقنين الاستبانة: بعد استخلاص قائمة مهار ات التعبير الثفهى فى صورتها

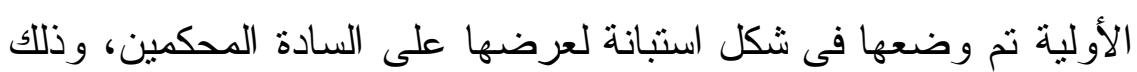

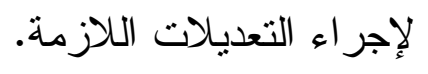

ث- ثبات الاستبانة: قامت الباحثة بالتأكد من ثبات استبانة مهــار ات التعبيـــر

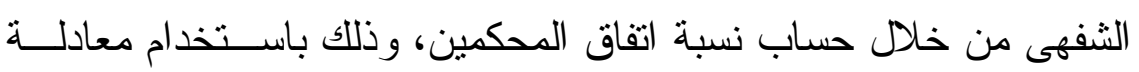

$$
\text { كوبر (Cooper) }
$$

ثانيا: إعداد اختبار مهار ات التعبير الثفهى:

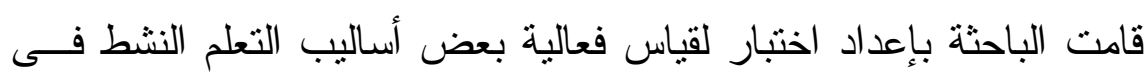

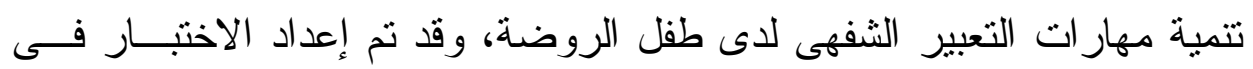
ضوء:

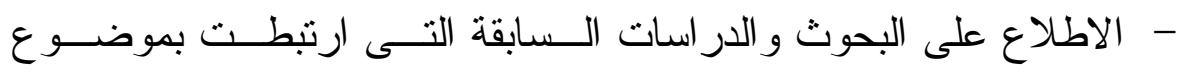
الدر اسة، و التى تهدف لتتمية مهار ات التعبير الثفهى.

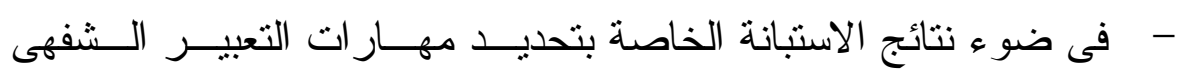
الو اجب تو افر ها لدى طفل الروضة. 
- مر اعاة خصائص التعبير الثفهى لدى طفل الروضة.

وفى ضوء الاعتبار ات السابقة تــم تــضمين المفــردات الخاصـــة بكــل

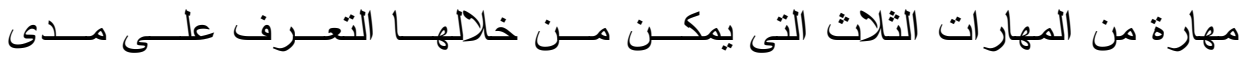

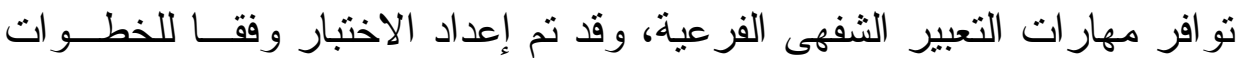

\section{أ- الهرف من الاختبار:}

يهدف هذا الاختبار إلى تحديد مهار ات التعبير الثفهى الفرعية التـى بهــا

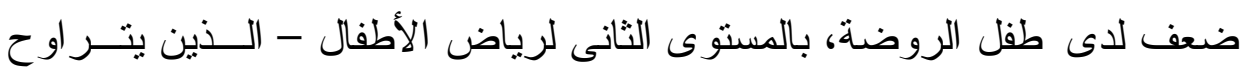
أعمار هم ما بين(-0-7) سنو ات، وتم ذلك من خلال بال

- استخدامه كاختبار قبلى لتعرف مدى تو افر مهار ات التعبير الثفهى لــدى

$$
\text { مجمو عتى الدر اسة (التجريبية، الضابطة). }
$$

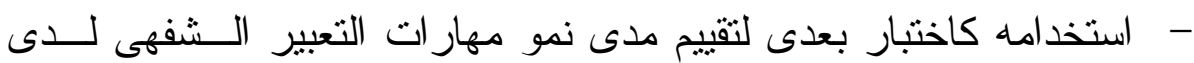

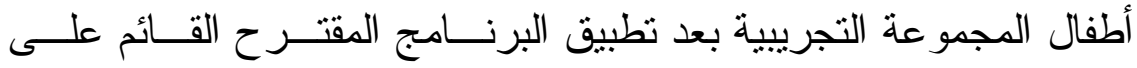

$$
\begin{aligned}
& \text { أساليب التعلم النشط فى ضوء الأحداث الجارية. } \\
& \text { ب- تحديا محتوى الاختبار: }
\end{aligned}
$$

تضمن الاختبار المهار ات الفرعية المرتبطة بمهار ات التعبيــر الــشفهىــ

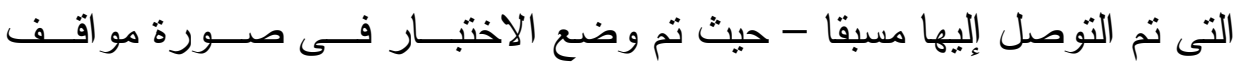

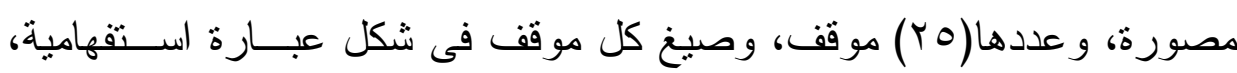
يعقبه تقديم بديلين، على أن يختار الطفل منها البديل الصحيح.

$$
\text { ج- وصف الاختبار : }
$$

يشمل الاختبار ثلاث مهار ات للتعبير الثفهى: 


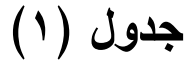

جدول المواصفات والأوزان النسبية للاختبار

\begin{tabular}{|c|c|c|c|}
\hline المئوية & المفردات & المفردات & أبعاد الاختبار \\
\hline$\%$ \% & 9 & $9: 1$ & استخدام اللغة المنطوقة فى التعبير عن الأفكار \\
\hline$\%$ \% & 9 & $11: 1$. & الفهم و الاستجابة لما بستمع إليه \\
\hline$\% \curlyvee \wedge$ & v & ro:19 & التو اصل الثفهي \\
\hline
\end{tabular}

د- تطبيق الاختيار وطريقة تصحيحه:

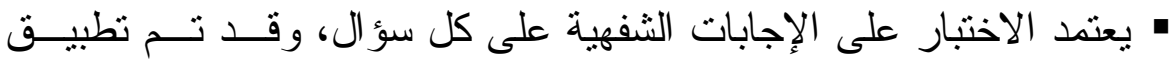
الاختبار بطريقة فردية على الأطفال وذلك بمساعدة المعلمة فى توضئيح

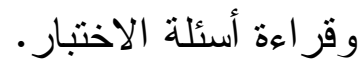

• وتم حساب زمن الاختبار وفقا لهتوسط أقل و أعلى زمن لإجر اء الاختبار، وقال

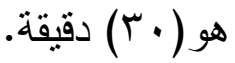

• وقد تم تصحيح الاختبار ليحصل الطفل على درجة واحدة عنـــــ الإجابــة اليـة

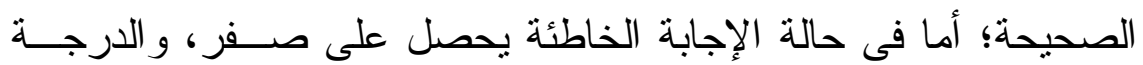

$$
\begin{aligned}
& \text { الكلية للاختبار (ro) درجة. } \\
& \text { ه- - إجراء الضبط العلمى للاختبار: }
\end{aligned}
$$

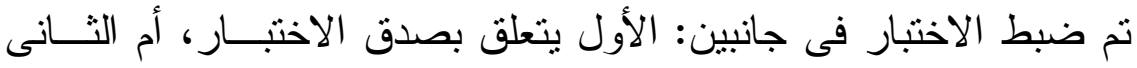
فيتعلق بثبات الاختبار ، كما هو موضح: هيط هانئ 


\section{أو لا: صدق الاختبار}

قامت الباحثة بحساب صدق اختبار مهارات التعبير الثفهى بالطريقتين التاليتين:

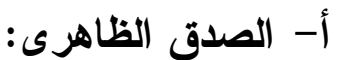

للتأكد من الصدق الظاهرى تم عرض الاختبار على مجموعة من المحكمين المتخصصين فى المناهج وطرق التدريس، ورياض الأطفال للتأكد من مدى صلاحيته كأداة للقياس فى هذه الدر اسة.

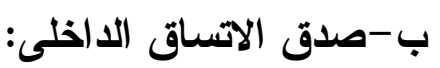
قامت الباحثة بإجر اء الاختبار على العينة الاســنطلاعية و التهى تكونــــ

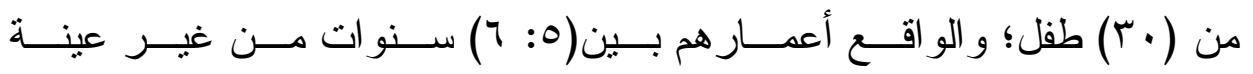

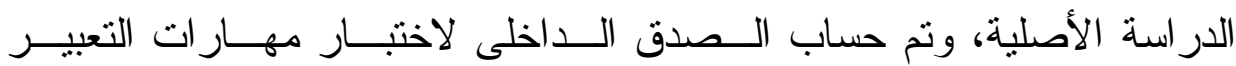
الشفهى. ثالثا: بناء البرنامج المقترح لتنمية مهارات التعبير الثفهى: تم بناء البرنامج المقترح وفق الخطو ات التالية : 1 - فلسفة البرنامج المقترح : • الاهتمام بنمو حواس الطفل وتدريبها. • جعل الطفل محور العمل بالروضة وليس المنهج أو المادة الدراسية. • توثيق التفاعل بين الطفل و البيئة من حوله . • تحقيق البرنامج بواســـة الأحـــاث الجاريسـة لتتميــة مهــارة التعبيــر الثفهى. 
r - أسس بناء البرنامج المقترح:

$$
\text { أ- أهداف رياض الأطفال }
$$

1- رعاية النمو المتكامل فى ظروف طباضل طبيعية سوية، وهى الظروف

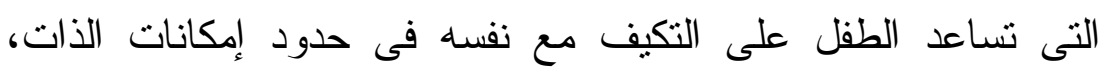

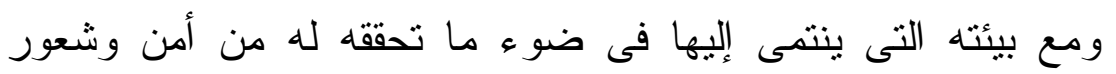

$$
\text { بالسعادة. }
$$

r- تهيئة الطفل لاستقبال أدوار الحياة على أساس سليم، وتعهده بالتتشئة

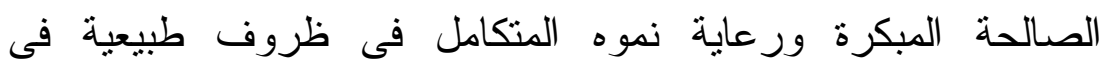

$$
\text { العلاقات الأسرية. }
$$

r- ت تهيئة الطفل للحياة المدرسية وتزويده بالمعلومات التى تتناسب مع نموه

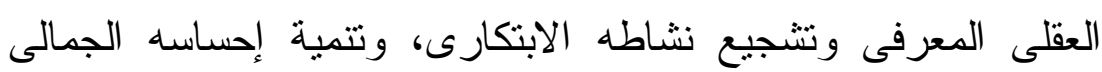

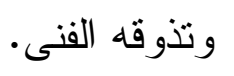

عـ - تدريب الطفل على المهار ات الحركية وتعويده العادات الصحية السليمة، وتهية

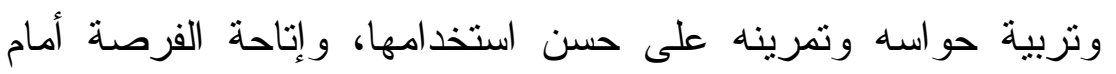

$$
\text { حيويته للانطلاق الموجه. }
$$

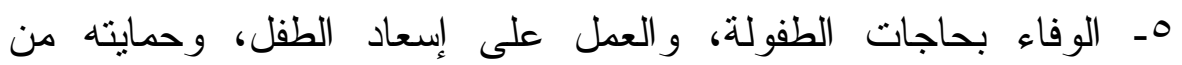

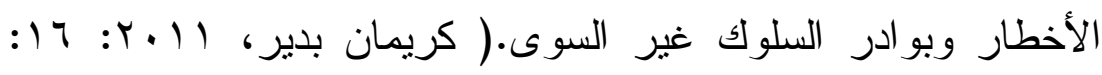

\section{ب-الاتجاهات التربوية المعاصرة فى تربية الطقل :}

تتطلب الاتجاهات المعاصرة فى التربية تقديم منهجا شاملا للطفل،

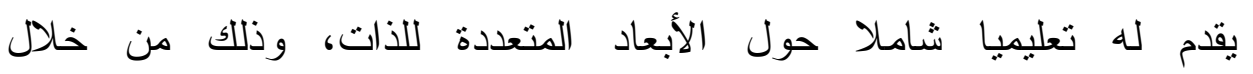

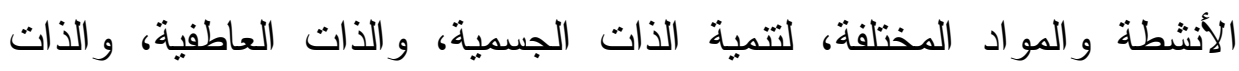

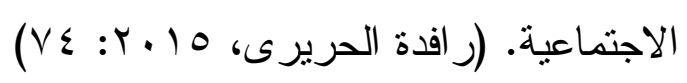


r- الإطار العام للبرنامج :

وفيما يلى عرض لهذه النقاط بشىع من التفصيل :

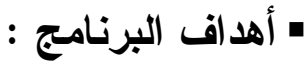

تعد الأهداف من أول و أهم الخطوات فى تـصميم أى برنـــامج، وتـشتشق

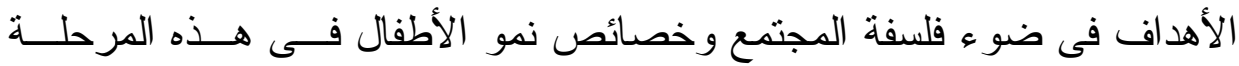
وطبيعة اللغة وكيفية تعليمها، وفلسفة التكامل فـى تعليمهــا، ويـسـاعد وضــع الأهداف فى اختيار المحتوى و الطريقة و الوسائل التى يتم بها تتفيذ البرنامج.

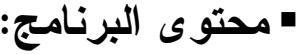

بعد تحديد الأهداف يجدر بنا تحديد محتوى البرنامج الـــى بمكنتـــا مــن تحقيق هذه الأهداف، وقد تم تصميم هذا البرنامج فى ثــلاثث وحــدات أساســية تحتوى كل منها عدد من الأنشطة التى تهدف لتتمية مهار ات التعبير الثفهى لدى هـى لهات الطفل.

\section{- الأشطة المتضمنة داخل وحدات البرنامج:}

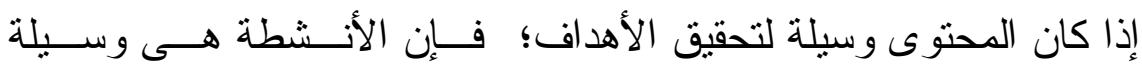
المحتوى، وتعد الأنشطة عبارة عن مجموعة مثتوعة من الممارسات يقـوم بهـــا الأطفال بقصد تتمية مهار ات التعبير الثفهى لديهم من خلال بعض أساليب التعلم النشط . (النش

• الأدوات و الوسائل التعليمية المستخدمة فى البرنامج : تساعد الأدوات على تحقيق الأهداف وتحسين محتوى التعلم؛ فهى تساهم فى إثارة عقل المتعلم وتقلل من نسبة نسيان المتعلم؛ حيث لا يتم التعليم بطريقة تقليدية، وتختلف الوسائل تبعا للأهداف و المحتوى وكذلك طريقة التدريس، فكل

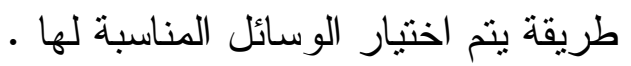




\section{• وسائل التقويم المستخدمة فى البرنامج : \\ وقد تم استخدام طرق التقويم التالية:}

ا - تقويم قبلى: حيث تم تطبيق اختبار مهار ات التعبير الثفهى قبل r- تقويم تكوينى: وهو تقويم مستمر من بداية البرنامج إلى نهايته، وتثتئل

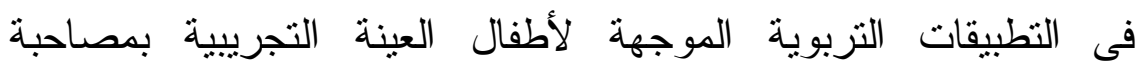
الأنثطة.

r- تقويم نهائى: وهو تقويم نهائى لفاعلية البرنامج المقترح، من خلال

$$
\text { تطبيق الاختبار بعديا . تونم: وهن }
$$

رابعا: تطبيق الاختبار قبليا على العينة (التجريبية، الضابطة)

$$
\text { جدول (r) }
$$

قيمة "ت" ودلالتها الإحصائية للفروق بين متوسطي درجات كل من

\begin{tabular}{|c|c|c|c|c|c|c|c|}
\hline \multicolumn{8}{|c|}{ الثفهى و الدرجة الكلية قبلياً } \\
\hline مستوى الدلالة & الدلالة & 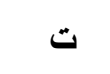 & د. & $\varepsilon$ & s & ن & مجموعتا الاراسة \\
\hline \multirow{2}{*}{ غير دالة } & \multirow{2}{*}{$\cdot$, Or } & \multirow{2}{*}{$\cdot, 7 \leqslant 1$} & $\uparrow$ & $1, .1$ & $\Lambda, \uparrow$. & ro & $ت$ \\
\hline & & & & $\cdot, \wedge 0$ & $\Lambda, \leqslant\rceil$ & ro & ض \\
\hline
\end{tabular}
المجموعة التجريبية والمجموعة الضابطة في مهارات اختبار التعبير

يتضح من الجدول السابق عدم وجود فرق ذو دلالة إحصائية بين

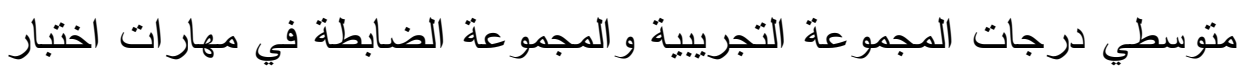

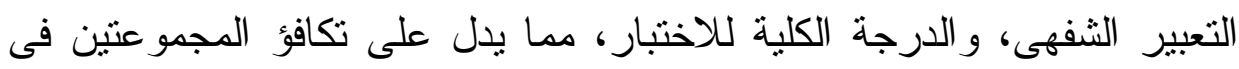
اختبار مهارات التعبير الثفهى القبلى. 
خامسا: تطبيق البرنامج المقترح على العينة التجريبية

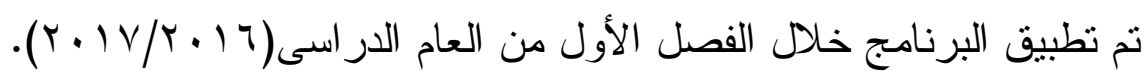
سادسا: تطبيق الاختبار بعديا على العينة(التجريبية، الضابطة)

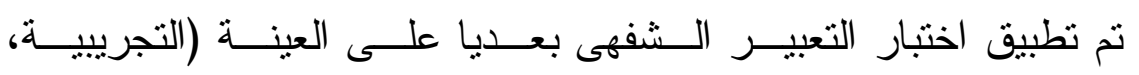
و الضابطة)، وتم تطبيقه أيضا على كل طفل بمفرده. الإطار النظرى: تم تناول الإطار النظرى للبحث من خلا محورين: المحور الأول: التعبير الثفهى: ويشمل(ماهية التعبير الثفهى، طبيعتهـ، أهميته، مهارات التعبير الثفهى لدى طفل الروضة:

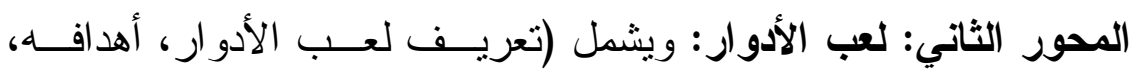

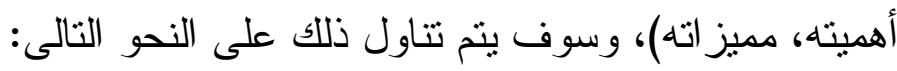
المحور الأول: التعبير الثفهى

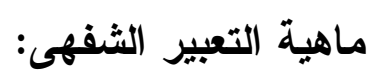

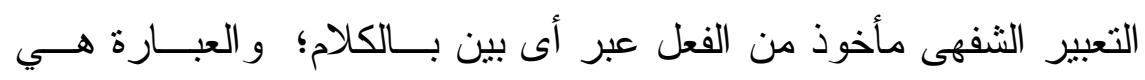

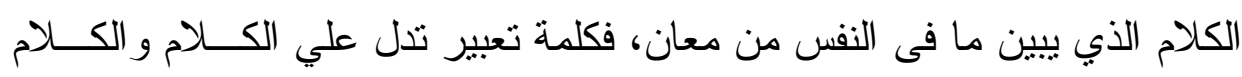

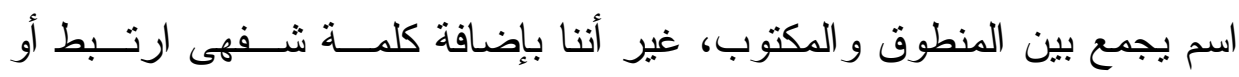

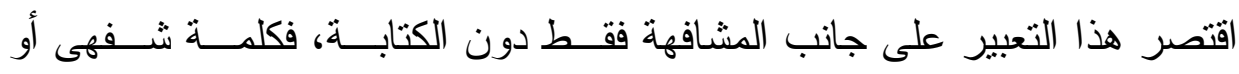

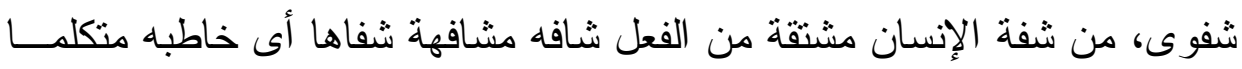

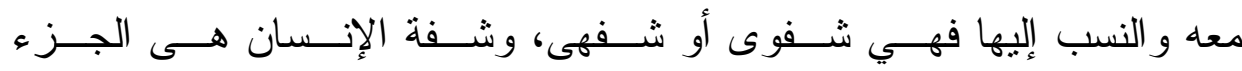

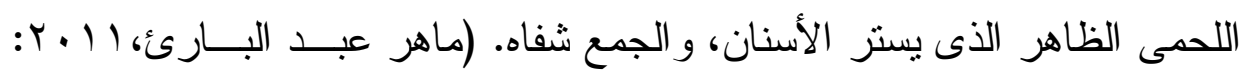
(1.0 
فاللغة الاستقبالية هامة جدا وضرورية لنمو اللغة التى يمكن أن ينتجها

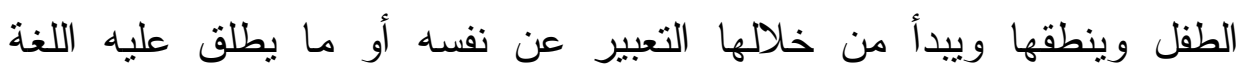

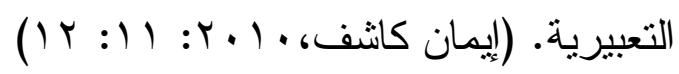

ويتسم طفل هذه المرحلة بأنه سريع فى النقاط كلمات جديدة، فقد يتحدث

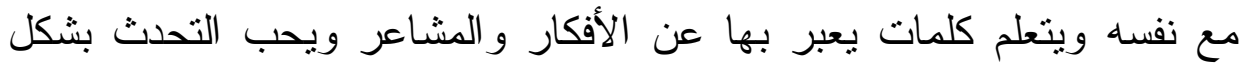
اجتماعى دائما، و اللغة الثفهية تستخدم للمشاركة و التعبير و اكتساب معرفة جديدة

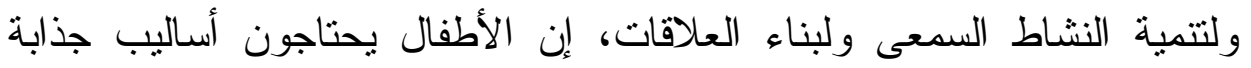
تحثهم على اللعب وتتمي التعاون وتتجع علي التفاعل اللفظى، وتجعهم يسعون للتعبير عن أفكارهم؛ لذا لابد من المعلمة أن تمنحهم الحرية و الديمقراطية بدلا

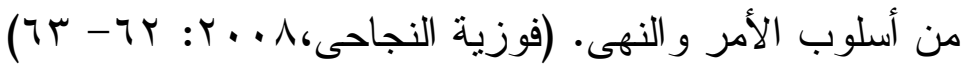

$$
\begin{aligned}
& \text { طبيعة التعبير الثفهى: }
\end{aligned}
$$

عملية التعبير الثفهى عملية معقدة تتم في ثلاث خطوات هى:

أ- الإستثثارة: فقلما أن يتحدث الطفل لابد أن بستثار، و المثير إما أن يكون

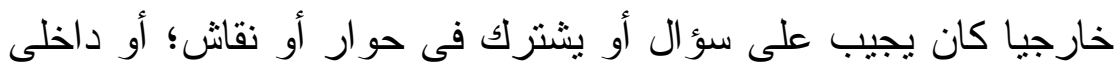

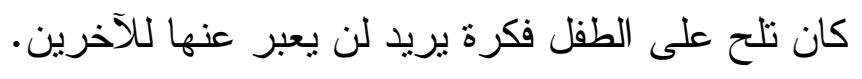

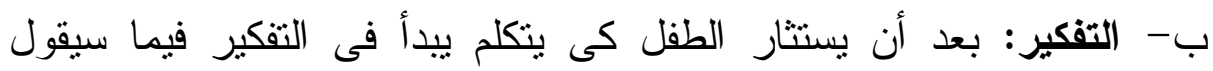

$$
\text { فيجمع الأفكار ويرتبها بطريقة منطقية. }
$$

ت- النطق: وهى المرحلة الأخيرة فى إنتاج الكلام؛ وهى أيضا المظهرئهر

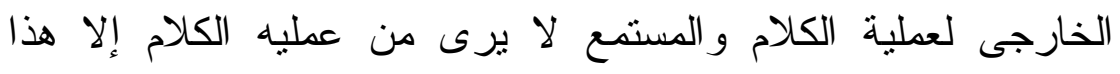

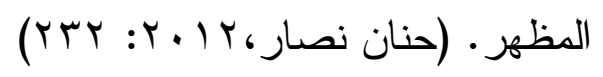




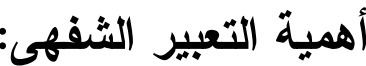

يستمد التعبير الثفهى أهميته من كونه كلام سبق الكتابة فى الوجود؛ فمن

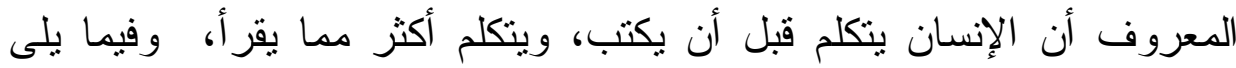

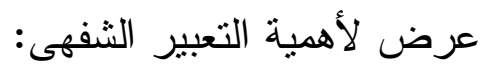
التعبير الثفهى الوسيلة التى يحقق بها الإنسان ذاته، ويعتبر أداة من أدوات الاتصال اللغوى و التى تشغل حيز ا كبير ا وزمنا لا بأس به فى نشاط الأنساط الإنسان اللغوى؛ حيث يشكل الثمرة المرجوة من تعليم اللغة وفنونها المختلفة،

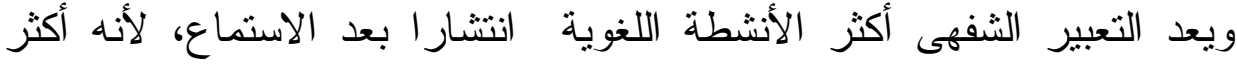
ممارسة، فهو يعلم صاحبه حسن التحدث و آداب الخطاب ويوجهه نحو احترام الآخرين، و التعرف على رغابتهم وميولهم عند الإستماع، ويعد التعبير الثفهى لفي

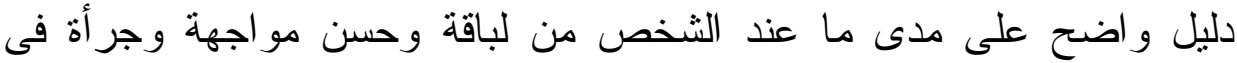
مواجهة الآخرين، إن التعبير الثفهى أساس أصيل فى التعامل بين المعلم

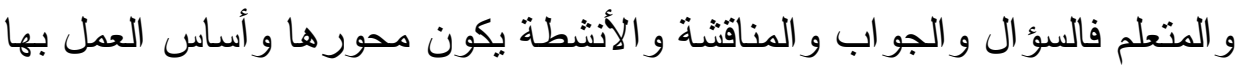
التحدث أو التعبير، فيتيح التعبير الثفهى فرصة لاكتساب مجالات اللياقة

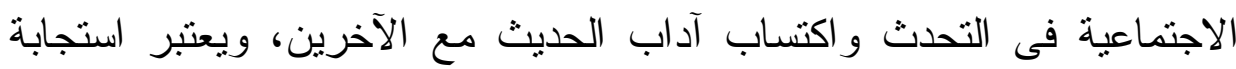

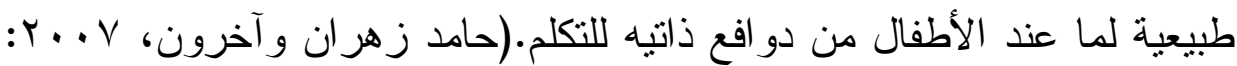
$(r 0 .-r \leqslant 9$

مهارات التعبير الثفهى لاى طقل الروضة من (ه: ؟) سنوات:

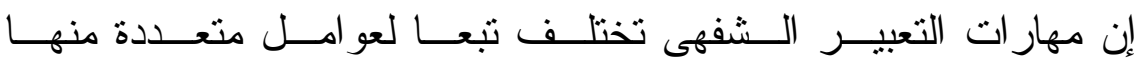
المرحلة الدر اسية، و العمر الزمنى، و المستوى العلمى، و واستر اتيجيات الخطـــاب،

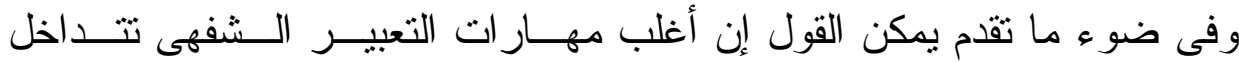

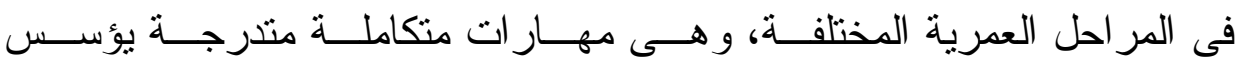




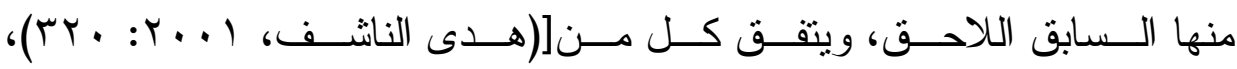

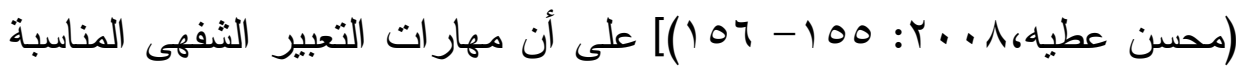
لطفل الروضة تتمنل فى الآتى: 1- يشير إلى 1 من أعضاء الجسم. r ب يذكر تعريف الأسماء الملموسة (أسماء الذوات). r- بحكى قصة من كتاب مصور أو صور ، بجمل مفهومه وسليمة. ــ - تقترب لغة الطفل وقو اعدها من لغة الكبار . 0ـ يأخذ دوره فى مناقثات بشكل مناسب. 7- يعطي ويستقبل معلومات. V- يحسن الاتصال بأفر اد الأسرة و الأصدقاء و الغرباء.

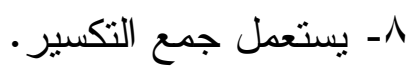

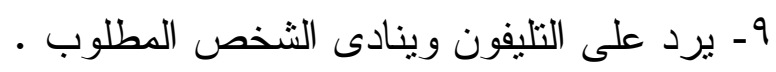
• 1 - اينقل رسالة شفوية من جز أين. 1ا - يتبع التعليمات المزدوجة بخصوص اليمين و اليسار . r ا - بنشد نشيد أو يغنى أغنية موزونة. rا ا - يتعرف شكل بعض الكلمات البسيطة ويقرؤها. ـ ا - يحسن النعبير الثفوى عن مشاعره و أفكاره. 10- يبادر إلى توجيه الأسئلة أو الحديث بجمل سليمة مع زملائه أو مع

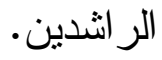




$$
\begin{aligned}
& \text { المحور الثاني: لعب الأدوار } \\
& \text { تعريف لعب الأدوار: }
\end{aligned}
$$

هو لعب درامى حيث يمثل الأطفال فيه شخصيات واقعية أو خيالية مستخدمين فى ذلك بعض الخامات والأدوات، وقد يقوم به طفل واحد أو

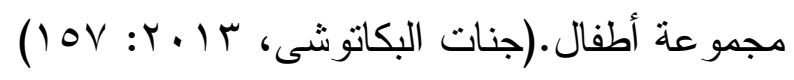

و هو أسلوب و اسع الاستخدام فى التعليم لاكتساب المهارات المعرفية، كما

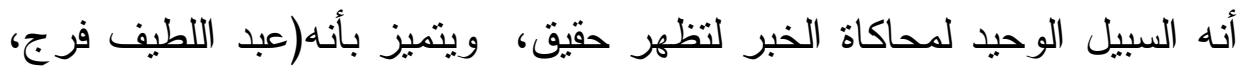

$$
\text { :() } 90: \text {. . . O }
$$

$$
\begin{aligned}
& \text { 1- يوفر فرص التعبير عن الذات وعن الانفعالات لاى الأطفال. } \\
& \text { r- يزيد من اهتمام الأطفال بموضوع الدرس المطروح. } \\
& \text { rـ تساعد فى التعرف على أساليب التفكير لدى الأطفال. } \\
& \text { ـ - تشجع روح التلقائية لديهم. }
\end{aligned}
$$

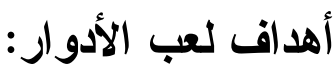

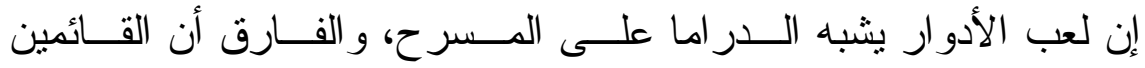

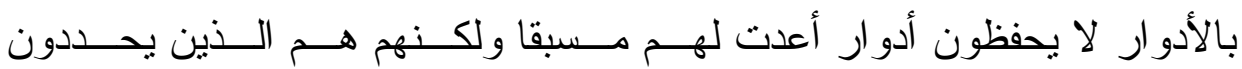

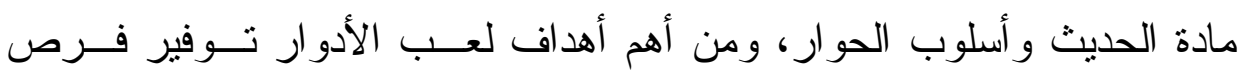

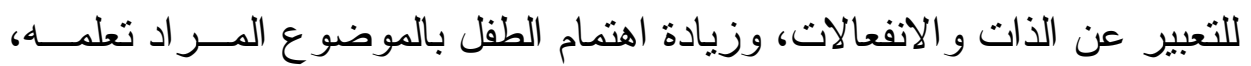

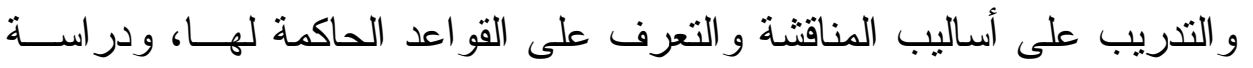
المشاعر الإنسانية و أساليب التفكير لاى الآخرين، وكذلك بناء القـيم و اكتـساب

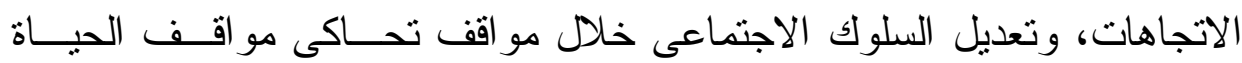


العقلية، وكما يتتاول لعب الأدوار المشكلات الاجتماعية بطريقة علميــة؛ حيــث تعرض المشكلة وتقسم تبعا الأدوار الأفر اد وفيها توزع الأدوار وتجرى المناقثنة

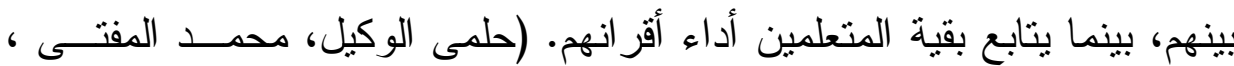
$(1 \leq \varepsilon: 1 \leq r: r \cdot) \leqslant$

\section{أهمية لعب الأدوار: - مبر}

حيث أن لعب الدور يؤدى أدوار ا ضرورية للطفل من النواحى الجـسمية و الفسيولوجية و الاجتماعية و العقلية و المعرفية، ففيما بتعلــق بــالنو احى العقليــة و المعرفية، نجد أن للعب الدور دور ا كبير ا فى نمو النشاط العقلـى و المعرفـى ونمو الوظائف العقلية العليا، فلعب الدور يساعد الطفل على أن يــدرك العــالم

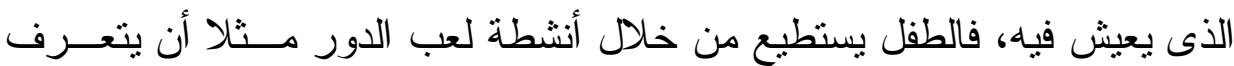

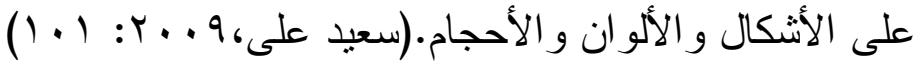

ولما كان لعـب الــدور بـستتد إلــى قــدرة الطفـلـل علــى الارتجـــال

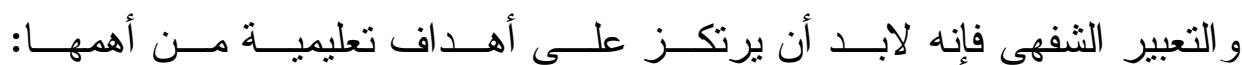
الإسهام فى كثف سمات السلوك المرغوب فيه وغير المرغوب فيه، يساعد على

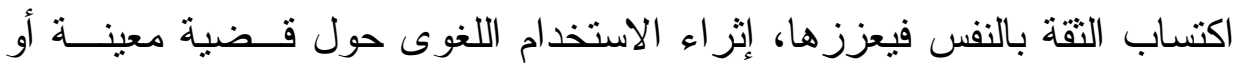

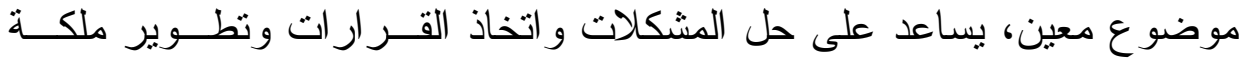

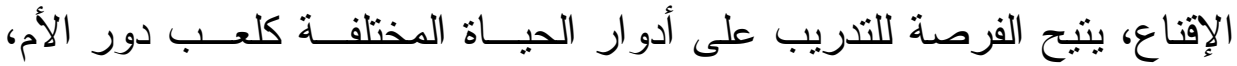
و الأب، وأصحاب المهن المختلفة، اكتشاف ميول الأطفال ورغباتهم ومــن ثــ

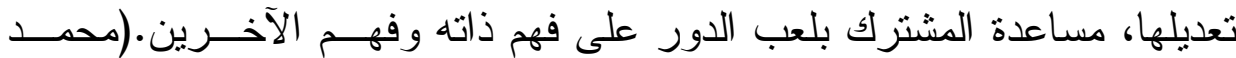

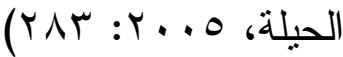

كما يشجع روح التلقائية لدى الأطفال، ويـساعد علــى التعـرف علـى

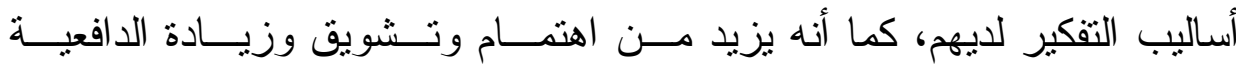


لدى الأطفال لـوضوع التعلم، وينمى لــديهم القــدرة علــى إقنــاع الآخــرين

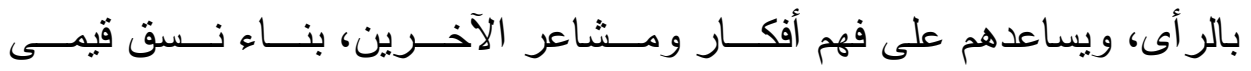

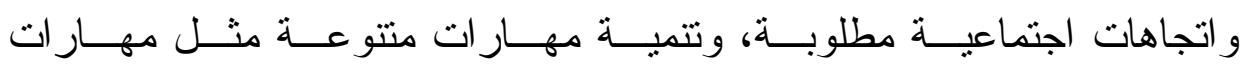

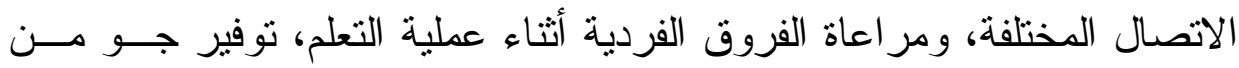

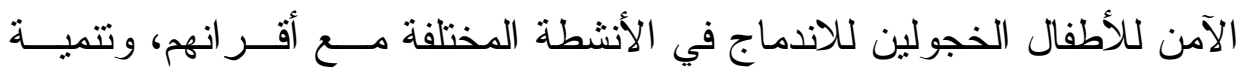

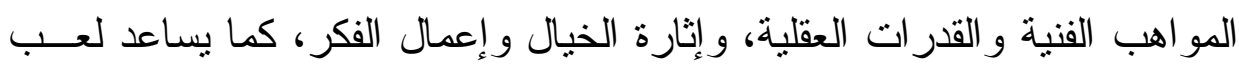

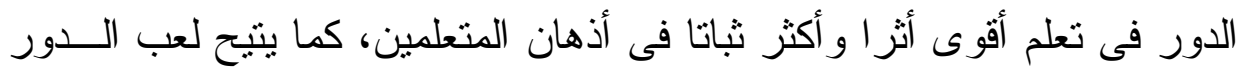

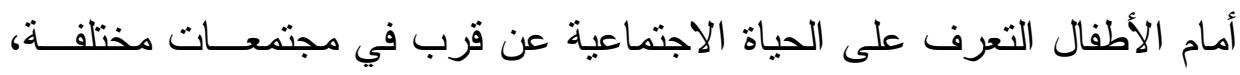

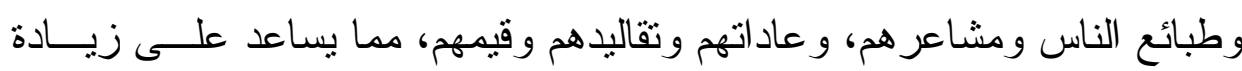
المعرفة بالثشعوب و الثقافات المختلفة.

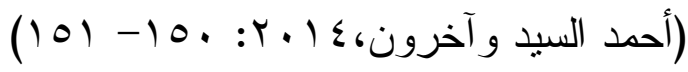

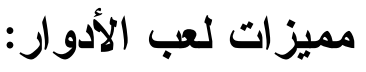

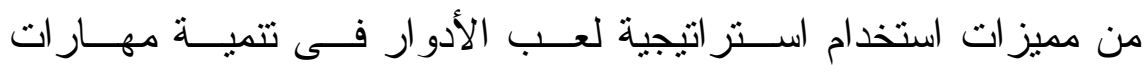
التعبير الثفهى؛ أنه يتيح للطفل التعبير عن العالم الو اقعى كما يـــــاه، و التعبيـــر

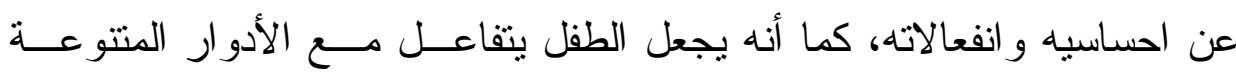

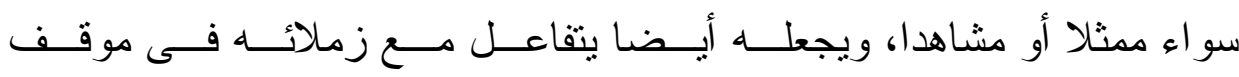

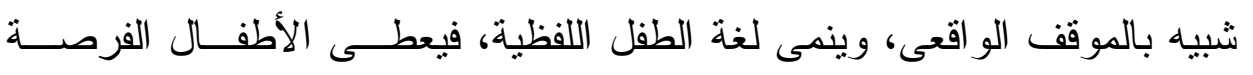

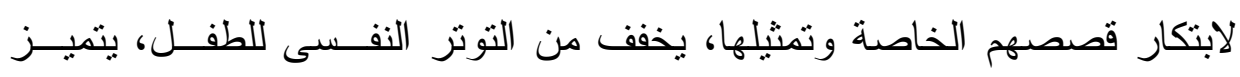

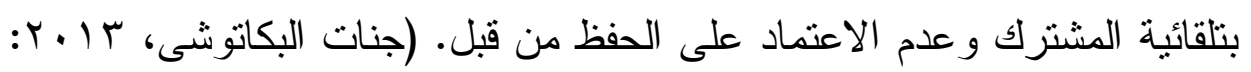
(109:101

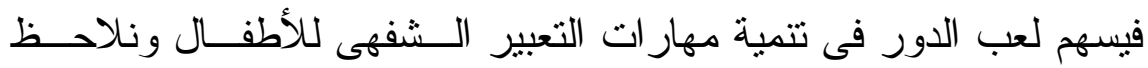

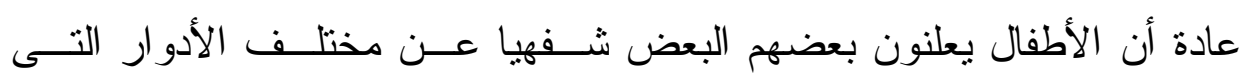


يقومون بها (سأقوم بدور الأب، و أنت بدور الأم، أمــــا الدميـة بــدور طفلنــا)

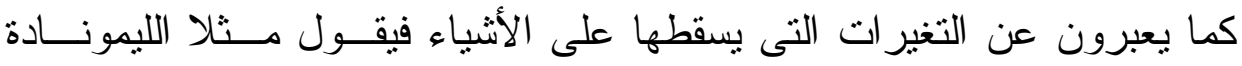

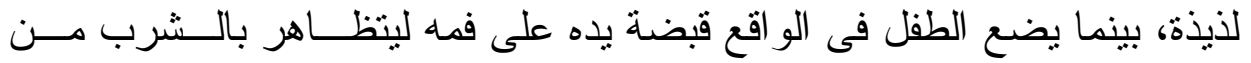

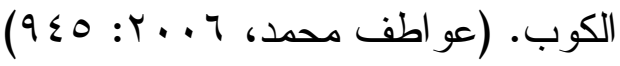

$$
\begin{aligned}
& \text { إجراعات الاراسة : }
\end{aligned}
$$

في ضوء مشكلة الاراسة وفروضها تمت الإجراءات على النحو التالى:

$$
\begin{aligned}
& \text { أولاً: إعداد استبانة مهار ات التعبير الثفهى } \\
& \text { ثانياً: إعداد اختبار مهار ات التعبير الثفهى إدى }
\end{aligned}
$$

ثالثا: بناء البرنامج المقترح وتحديد الأنشطة التى تساهم فى تتمية بعض

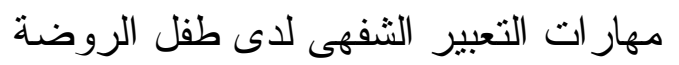

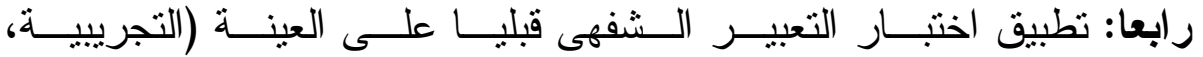

$$
\text { و الضابطة). }
$$

خامسا: تطبيق البرنامج المقترح على(العينة التجريبية) لتتمية مهارات التعبير الثفهى.

سادسا: تطبيق اختبار التعبيــر الــثفهى بعـديا علـى العينــة(التجرييــة،

$$
\text { و الضابطة). }
$$

سابعا: تفسير النتائج فى ضوء نتائج التجربة . ثنامنا: التوصيات و المقترحات. 


\section{سابعا: تفسير النتائج فى ضوء نتائج التجربة}

ولما كان الهدف الرئيسى من إجر اء هذه الدراســة هـــ التعـرف علـى

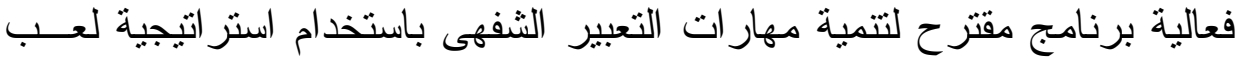

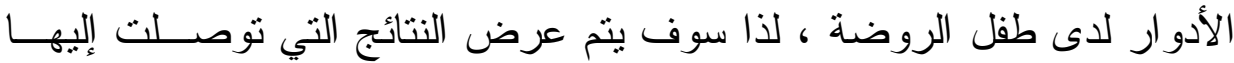

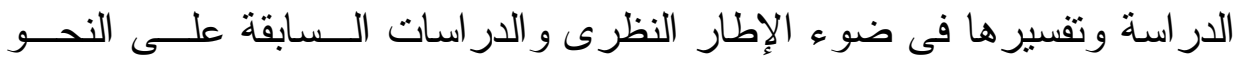

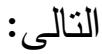
الفرض الأول: " يوجد فرق ذو دلالة إحصائية عند مستوى دلالة (0.05) بين متوسطى درجات أطفال المجموعتين (الضابطة والتجرييية) في النطبيق البعدى لاختبار التعبير الثفهى لصالح المجموعة التجرييية

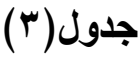

قيمة "ت" ودلالتها الإحصائية للفروق بين متوسطى درجات كل من المجموعتين (التجريبية والضابطة) في اختبار مهارات التعبير الثفهى و الارجة الكلية بعدياً

\begin{tabular}{|c|c|c|c|c|c|c|c|}
\hline الالالة & ت & د. د. & $\varepsilon$ & م & $\dot{0}$ & مجموعتا & اختبار مهارات التعبير الشفهى \\
\hline \multirow{2}{*}{ 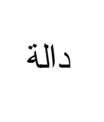 } & $9, \vee 7$ & 71 & 1,01 & $7, .9$ & ro & ت & \multirow{2}{*}{ فى التعبير امن اللغة المنطوقة } \\
\hline & & & 1, & $r, 7 q$ & ק & ض ض & \\
\hline \multirow{2}{*}{ د الة } & $1 \cdot, r \wedge$ & $7 \wedge$ & $1, r_{1}$ & $7, r \varepsilon$ & ק r & $ت$ & \multirow{2}{*}{ لما بستم و الاستجابة } \\
\hline & & & $1, \varepsilon 1$ & $r, 11$ & ro & ض & \\
\hline \multirow{2}{*}{ د لة } & $V, T V$ & $7 \wedge$ & $1, r \wedge$ & $\varepsilon, O V$ & ro & ت & \multirow{2}{*}{ التو اصل الثفهىى } \\
\hline & & & 1,1 & $r, r q$ & ro & ض & \\
\hline \multirow{2}{*}{ 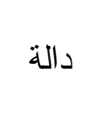 } & $\mid r, 11$ & $7 \wedge$ & ఛ, §૫ & iv & ro & ت & \multirow{2}{*}{ الاختبار ككل } \\
\hline & & & $r, 70$ & $1, \cdot 9$ & ro & ض & \\
\hline
\end{tabular}


يتضح من الجدول السابق وجود فرق ذو دلالة إحصائية بين منوسطى

درجات المجموعة التجريبية و المجموعة الضابطة فى المهار ات المتضمنة بالاختبار و الدرجة الكلية للاختبار •

وفى ضوء النتائج السابقة تم قبول القرض الأول: "يوجد فرق ذو دلالة إحصائية عند مستوي دلالة (0.05 ) بين متوسطي درجات أطفال المجمو عتين (الضابطة والتجريبية) في التطبيق البعدي لاختبار التعبير الثفهى لصالح

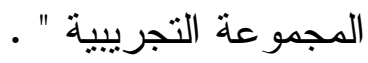

وترجع الباحثة الفرق بين متوسطى درجات المجموعتين(التجريبية، و الضابطة)، و الذى كان لصالح المجمو عة التجريبية إلى:

استخدام استر اتيجية لعب الأدوار أثناء تدريس البرنــامج المقترح؛و التــى ساعدت فى زيادة مهار ات التعبير الثفهى لدى المجموعة التجريبية، فـى حين أن المجموعة الضابطة تخضع لطرق التدريس التقليدية.

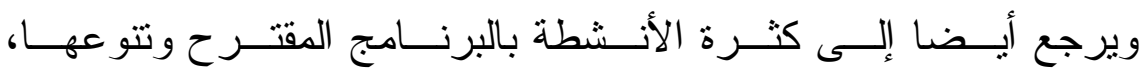

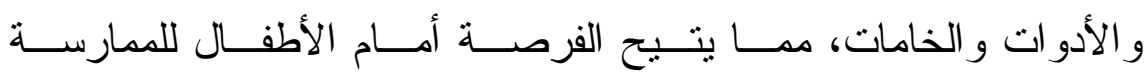

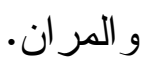
شغف هؤ لاء الأطفال لتتمية مهــار ات التعبيــر الــشفهى دون إدر اكهـم،

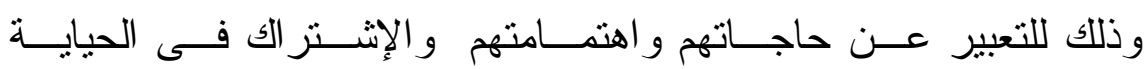

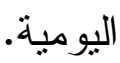
وتتقق هذه النتائج بصفة عامة مع در اســة كــلا مــن: حنــان نــصـار

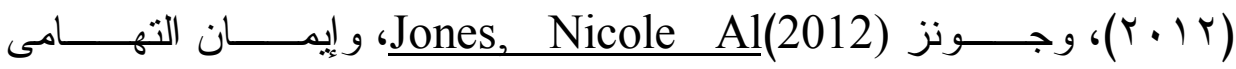

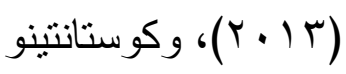


Costantino-Lane, Tina (2013) و و أيضا كوبف Kopf, D.(2013)

الفرض الثاني: " يوجد فرق ذو دلالة إحصائية عند مسنوي دلالة(0.05) بين منوسطي درجات أطفال المجموعة التجريبية في النطبيقين (القبلي و البعدي) لاختبار مهار ات التعبير الثفهى قبل وبعد تقديم البرنامج الدقتر ح لصالح التطبيق

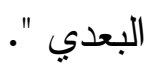

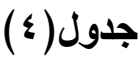

قيمة "ت" ودلالتها الإحصائية للفروق بين متوسطي درجات كل من التطبيقين (القبلي و البعدي) للمجموعة التجريبية في المهارات الرئيسة لاختبار التعبير الثفهي و الارجة الكلية

\begin{tabular}{|c|c|c|c|c|c|c|c|}
\hline مستوى الالاكة & ت & د. & $\varepsilon$ & م & $\dot{ن}$ & القياس & اختبار مهار ات التعبير الشفهى \\
\hline \multirow{2}{*}{ 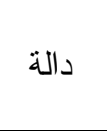 } & \multirow{2}{*}{$\Lambda, \vee T$} & \multirow{2}{*}{ rz } & 1,01 & $7, \cdot 9$ & o & بعدى & \multirow{2}{*}{ فى التعبير عن اللغة المنطوقة } \\
\hline & & & $\cdot, 90$ & $r, O V$ & ס r & قبلى & \\
\hline \multirow{2}{*}{ 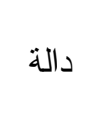 } & \multirow{2}{*}{11,91} & \multirow{2}{*}{ TE } & $1, Y_{1}$ & $\tau, \Gamma \varepsilon$ & ro & بعدى بع & \multirow{2}{*}{ لما يستمع و الاستجابة } \\
\hline & & & $\cdot, 9 \wedge$ & $r, q 1$ & o r & قبلى & \\
\hline \multirow{2}{*}{ دالة ل } & \multirow{2}{*}{$\Lambda, T r$} & \multirow{2}{*}{ rs } & גז, & $\varepsilon, O V$ & ס r & بعدى & \multirow{2}{*}{ التو اصل الثفهى } \\
\hline & & & מ & $r, 11$ & o r & قبلى ق & \\
\hline \multirow{2}{*}{ 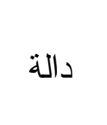 } & \multirow{2}{*}{ IT,TV } & \multirow{2}{*}{ rs } & $\Gamma, \leqslant\rceil$ & iv & ro & بعدى & \multirow[t]{2}{*}{ الاختبار ككل } \\
\hline & & & $1, \cdot 1$ & $\Lambda, 7$ & ro & قبلى & \\
\hline
\end{tabular}

يتضح من الجدول السابق وجود فرق ذو دلالة إحصائية بــين متوســي

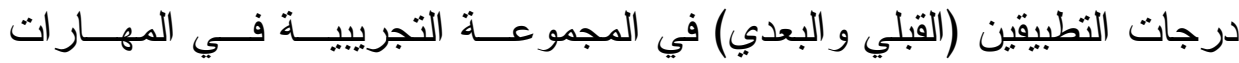
الرئيسة لاختبار مهار ات التعبير الثفهى و الدرجة الكلية للاختبار . 
وفي ضوء تللك النتائج، يمكن قبول الفرض الثاني" يوجد فرق ذو دلالــــة

إحصائية عند مستوي دلالة(0.05) بين متوسطي درجــات أطفــال المجموعـــة التجريبية في التطبيقين (القبلي و البعدي) لاختبار مهار ات التعبير الـشفهى قبـلـل وبعد تقديم البرنامج المقترح لصالح التطبيق البعدي ".

وترجع الباحثة الفرق بين متوسطى درجات المجموعة التجريبيــة علــى الاختبار ، و هذا التحسن فى أدائهم إلى استخدام استر اتيجية لعب الأدو ار حيث قام

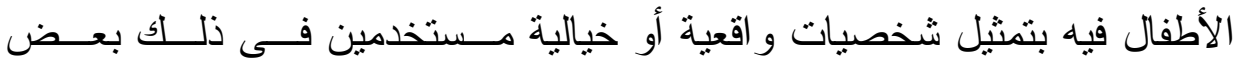
الخامات و الأدو ات، وقد يقوم به طفل و احد أو مجموعة من الأطفــال، وكـــللك إخضاع الأطفال للمو اقف اليومية المرنبطة بحياتهم مثـل لعــب دور الأم والأب

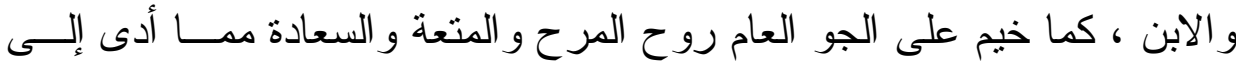
زيارة دافعية الأطفال على الأداء، مما ساعد فى تحقيق الأهداف المرجوة، وتتفق

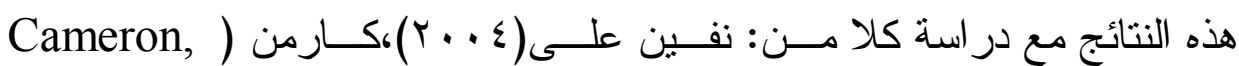

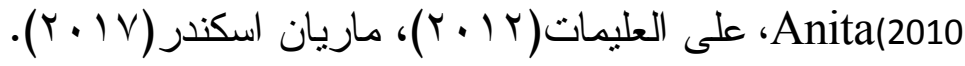
ثامنا: التوصيات و المقترحاث

\section{التوصيات}

في ضوء النتائج التى توصلت إليها الدر اسة يمكن تقديم التوصيات التالية:

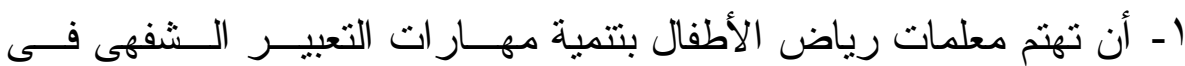

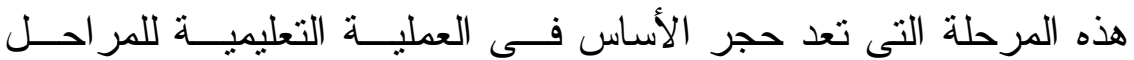
التعليمية.

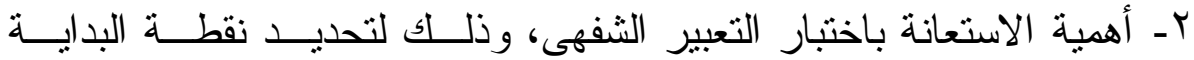
لمستوى الأطفال و الوقوف على نقاط الضعف لديهم. 
r- استعانة المعلمات بالدر اسات الحديثة التى تهتم بتتمية مهـار ات التعبيـر

$$
\text { الثفهى منل الدر اسة الحالية. }
$$

ع - استخدام أساليب التعلم النشط المناسبة لطفل الروضة و التــى نزيـــــــن

$$
\text { استغلال امكانيته. }
$$

0ـ عقد الدورات و الورش التدريبة تحت إنثر اف كلية رياض الأطفال لتتميـــة معلمات رياض الأطفال مهنيا فى مجال تتمية لغة الطلف.

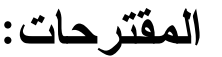

فى ضو ء ما أسفرت عنه نتائج الدر اسة الحالية، تقترح الباحثة الدر اسات الثالية: 1 - فاعلية استخدام أساليب التعلم النشط فى تتمبة مهارة الاستعداد للقر اءة لاى

$$
\text { طفل الروضة فى ضوء الأحداث الجارية. }
$$

r- فاعلية استخدام أساليب التعلم النشط فى تتمية مهارة الاستعداد للكتابة لدى

$$
\text { طفل الروضة فى ضوء الأحداث الجارية. }
$$

r- استخدام أساليب التعلم النشط فى تتمية مهــار ات التو اصــل لــدى طفــلـ

$$
\text { الروضة فى ضوء الأحداث الجارية. }
$$

ع- مقارنة أثز استخدام أساليب التعلم النشط فى تتمية مهارة التعبير الــشفهي

$$
\text { و احدى الطرق النقليدية في تعليم لدى طفل الروضة. }
$$

0ـ فاعلية استخدام أساليب التعلم النشط فى تتمية مهارة التعبير الثفهى لذوى

$$
\text { الاحتياجات الخاصة فى مرحلة الروضة. }
$$


أولا: المراجع العربية: - أن

1- أحمد رمضان السيد وآخرون: فاعلية وحدة مقترحة فى الدراسات الاجتماعية قائمة على استراتيجية لعب الأدوار لتلاميذ الصف السادس

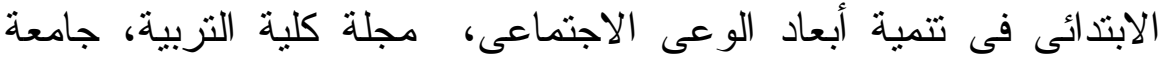

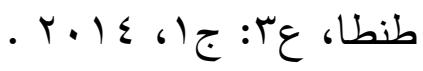

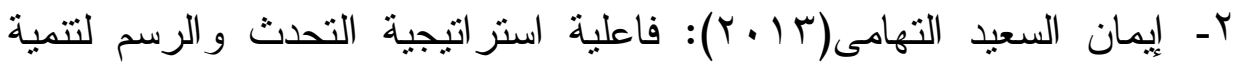

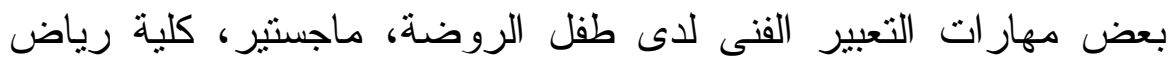

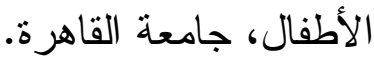
r- إيمان فؤاد الكاثف( • • ب): مشكلات الكلام و اللجلجة، طا، القاهرة، دار

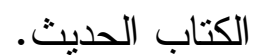

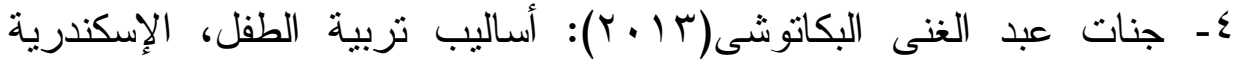
(ج.ج.ع)، دار الجامعة الجديدة.

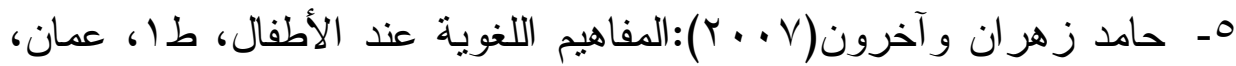

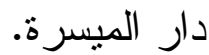

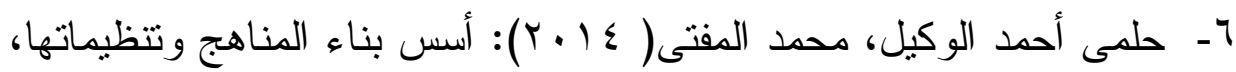
طV، عمان، دار المسيرة للنشر و التوزيع و الطباعة. V - حنان محمد نصار : فاعلية استخدام الصور فى النثاط القصصي فى تحسين الأداء اللغوى الثفهي وفهم القصة لدى أطفال الروضة، مجلة الطفولة الطفان

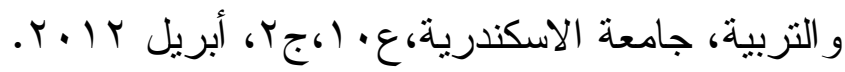
ᄉ- ر رافدة عمر الحريرى (10 بـ): نثأة وإدارة رياض الأطفال، طس، عمان، دار المسيرة. 


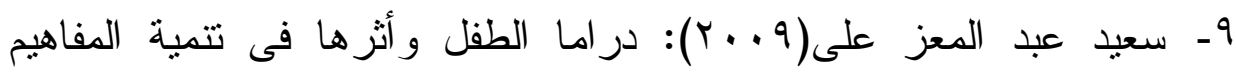
الحياتية لطفل الروضة، طاء القاهرة، عالم الكتب.

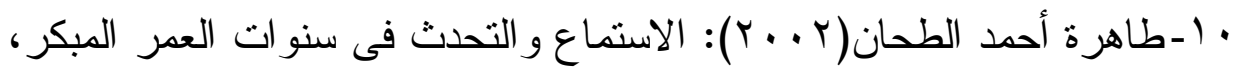

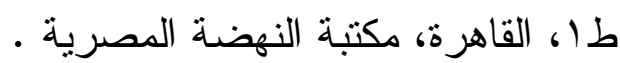

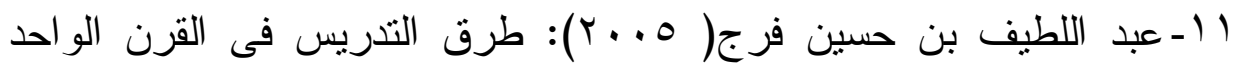

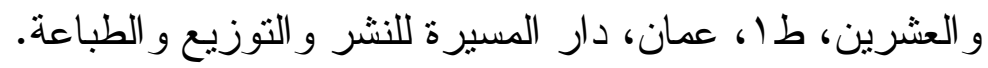

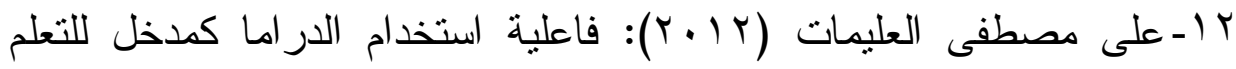
النشط لتتمية بعض المهارات المهنية لاى معلمات رياض الإليات الاطفال، دكتور اه، كلية رياض الأطفال، جامعة القاهرة.

rا - عو اطف إبر اهيم محمد: حق الطفل فى ألعاب الدراما الاجتماعية، المؤتمر

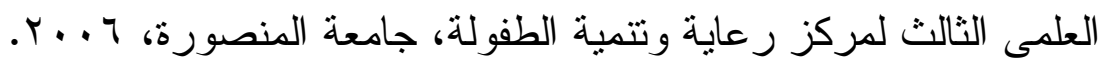
ع ا-فاطمة عبد الرؤف هانثم(7 ( • ץ): مسرح ودر اما الطفل، طا، الرياض،

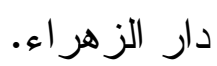

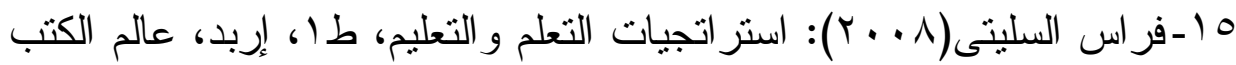
الحديث.

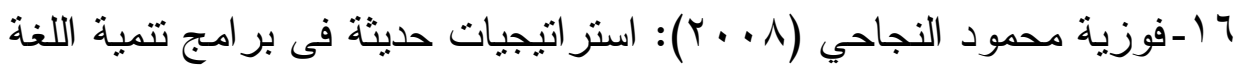

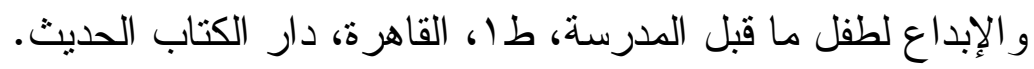

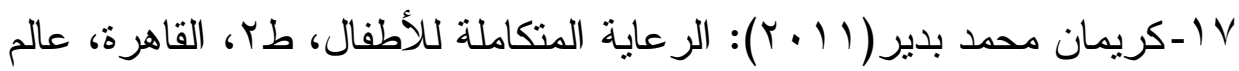

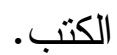

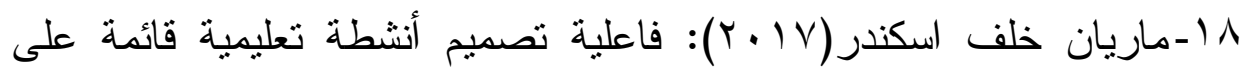

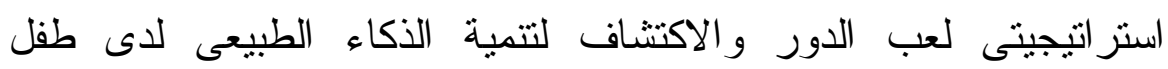
الروضة، ماجستير ، كلية التربية، جامعة حلو ان. 
9 اـماهر شعبان عبد البارئ(|(1 +r): مهار ات الاستماع النشط، طا، عمان،

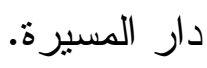

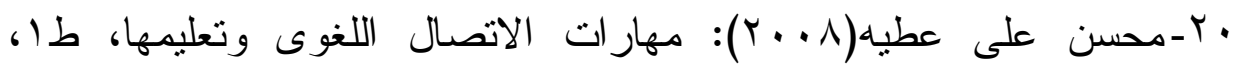
عمان، دار المناهج للنشر و التوزيع.

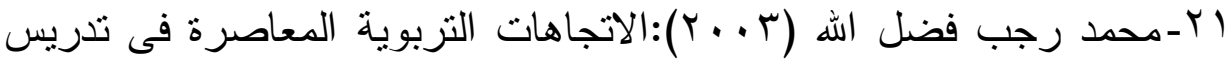

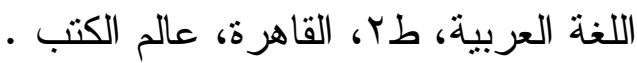

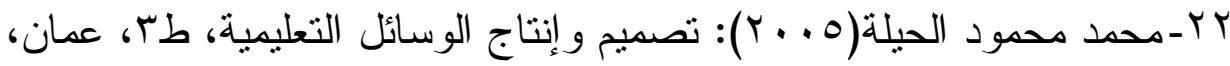

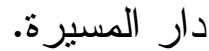

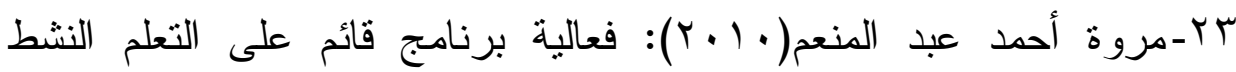
و المشاركة الأسرية فى ضوء التعلم للعيش معا لإعداد طفل الروضة لإنة للحياة

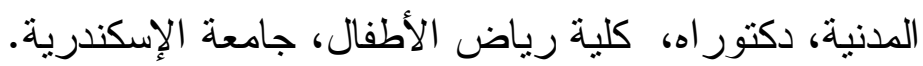

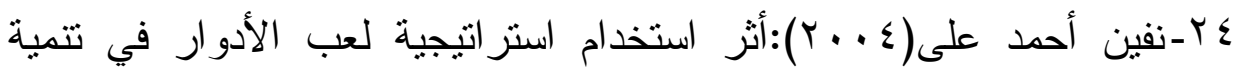

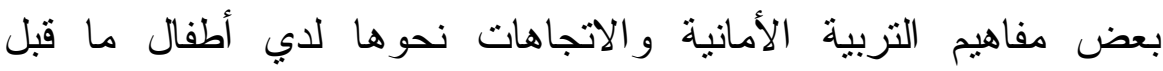

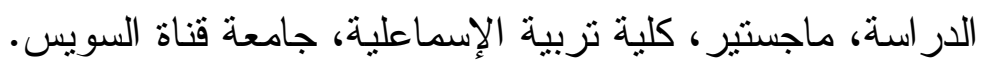

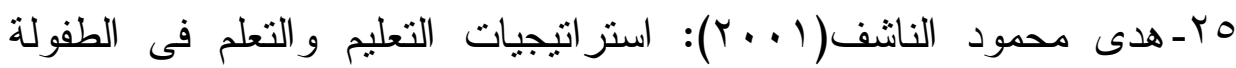
المبكرة، القاهرة، دار الفكر العربى.

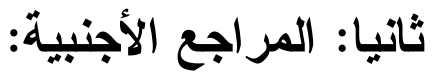

26- Cameron, Petronella Anita(2010): Preschool Environments, Relationships and Creative skills: A case study, Ph.D., Walden University. https://search. proquest. com/docview/822603425? accountid=37571 
27- Costantino-Lane, Tina(2013): Kindergarten Teachers' Perceptions of The Relationship Between Oral Language and Reading Achievement of Kindergarten Students and The Impact of State Standards and Educational Policy, Ed.D., Azusa Pacific University.http://search.proquest. com $/$ docview $/ 1328381642$ ?accountid=27191

28- Jones, Nicole Alissa.(2012): Preschool Educators' Perceptions of Practice in Facilitating/modeling Oral Language Acquisition and Development, Ed.D. ,Loyola University Chicago. http://search.proquest.com/ pqdtglobal/ docview/1069261897/fulltextPDF/B625DF 4643241C0PQ/14?accountid=37571

29- Kopf, Sigrid D.(2013): Impacting Oral Language in Kindergarten Through Sophisticated Vocabulary and the Kinesthetic Modality, Ed.D., Widener University . http://search.proquest.com/docview/1441958535?account id $=27191$ 